\title{
ANALISIS KANDUNGAN Cd, Cu DAN Pb PADA AIR PERMUKAAN DAN SEDIMEN PERMUKAAN DI MUARA-MUARA SUNGAI KOTA PADANG
}

\author{
Sri Yenica Roza, Leila Muhelni \\ Jurusan Manajemen Sumber Daya Perairan Fakultas Kelautan dan Perikanan \\ Universitas Nahdlatul Ulama Sumatera Barat \\ Email: sriyenicaroza@gmail.com
}

\begin{abstract}
Abstrak
Pencemaran logam berat terhadap lingkungan berasal dari aktivitas manusia di laut maupun di darat. Hal ini dapat menimbulkan pengaruh negatif terhadap lingkungan perairan terutama organisme yang hidup di dalamnya dan manusia yang mengkonsumsi organisme tercemar. Penelitian ini bertujuan mengetahui kandungan logam berat $\mathrm{Cd}, \mathrm{Cu}$ dan $\mathrm{Pb}$ pada biota air permukaan dan sedimen permukaan di perairan Kota Padang. Penelitian ini dilaksanakan pada Bulan Mei 2018. Lokasi sampling ditetapkan pada 4 muara sungai besar di Kota Padang. Kandungan logam $\mathrm{Pb}, \mathrm{Cu}$ dan $\mathrm{Cd}$ dianalisis menggunakan AAS (Atomic Absorbtion Spectrophotometry). Kandungan logam Cd pada air berkisar antara 0.0167-0.0374 mg/l, sedangkan kandungan Cd pada sedimen berkisar antara 0.241-0.653 (mg/kg). Nilai Cd pada air permukaan diatas nilai baku mutu air laut untuk biota hidup. Kandungan logam $\mathrm{Cu}$ pada air berkisar antara 0.0155-0.0365 mg/l, sedangkan kandungan Cd pada sedimen berkisar antara 0.128-0.424 (mg/kg). Kandungan logam Pb pada air berkisar antara 0.0155-0.0378 mg/l, sedangkan kandungan $\mathrm{Pb}$ pada sedimen berkisar antara 0.0265-0.225 (mg/kg). Secara umum, kandungan logam berat pada sedimen permukaan nilainya lebih tinggi dari pada kandungan logam berat di air permukaan karena mudah terakumulasi dan terendapkan pada sedimen permukaan.
\end{abstract}

Kata Kunci: Logam Berat, Air Permukaan, Sedimen, Kota Padang

\section{THE STUDY OF Cd, Cu, AND Pb COMPOUNDS ON SURFACE WATER AND SEDIMENTS IN THE ESTUARIES OF PADANG}

\begin{abstract}
Metal pollution on the environment comes from human activities at sea and on land. It provides negative effect to the aquatic environment, especially organisms which are involved in it and humans who consume contaminated organisms. the aim of this research is to know the contents of heavy metal of $c d, c u$, and $P b$ on the surface water biota and surface sediment in the waters of Padang. This research was conducted in May 2018. The sampling location was established in 4 big river estuaries in Padang. Metal content of $\mathrm{Pb}, \mathrm{Cu}$ and $\mathrm{Cd}$ were analyzed by using AAS (Atomic Absorption Spectrophotometry). The metal content of $C d$ in water ranged from 0.0167-0.0374 $\mathrm{mg} / \mathrm{l}$, while the $C d$ content in sediment ranged from 0.241-0.653 $(\mathrm{mg} /$ $\mathrm{kg})$. The Cd value in surface water is above the sea water quality standard for living biota. The content of Cu in water ranged from 0.0155-0.0365 mg / l, while the Cd content in sediments ranged from 0.128-0.424 ( $\mathrm{mg} / \mathrm{kg}) . \mathrm{Pb}$ metal content in water ranged from 0.0155-0.0378 mg / l, while the Pb content in sediments ranged between 0.0265-0.225 ( $\mathrm{mg} / \mathrm{kg})$. In general, the heavy metal content in surface sediments is higher than heavy metals in surface water due to it is easily accumulated and deposited on surface sediments.
\end{abstract}

Keywords: Heavy Metal, Sea, Sediment, Padang

\section{PENDAHULUAN}

Pencemaran logam berat dapat menimbulkan pengaruh negatif terhadap lingkungan perairan terutama organisme yang hidup di dalamnya dan manusia yang mengkonsumsi organisme tercemar. Pencemaran logam berat terhadap alam lingkungan estuaria merupakan suatu proses yang erat hubungannya dengan penggunaan logam berat oleh manusia (Rochyatun et al, 2006).

Sumber logam berat bisa berasal dari aktivitas manusia di laut maupun di darat. Aktivitas di laut berasal dari pembuangan sampah-sampah, air ballas dari kapal, penambangan logam di laut, penambangan minyak lepas pantai, kecelakaan kapal tanker dan lain-lain. Aktivitas manusia di darat dapat berasal dari limbah-limbah domestik, limbah perkotaan, pertambangan, pertanian dan perindustrian serta asap-asap kendaraan (Amin 2012). Selain mencemari air, logam berat juga akan mengendap di dasar perairan yang mempunyai waktu tinggal (residence time) sampai ribuan tahun dan logam berat akan terkonsentrasi kedalam tubuh makhluk hidup dengan proses bioakumulasi dan biomagnifikasi melalui beberapa jalan yaitu: melalui saluran pernapasan, saluran makanan dan melalui kulit (Darmono, 2001).

Kota Padang berada di kawasan pantai barat Pulau Sumatera, merupakan wilayah pesisir pantai yang sangat potensial pada bidang perikanan laut. Kota Padang dialiri beberapa sungai besar dan bermuara ke pantai barat Pulau Sumatera. Sungai ini berada di sepanjang aliran urban (kawasan pemukiman dan industri). Pemanfaatan sungai di Kota Padang ini cukup beragam diantaranya untuk perikanan, tempat pelabuhan kapal, tempat pembuangan limbah pabrik karet dan sebagai daerah rekreasi (Yanti EL dan Afdal, 2016).

Hasil penelitian Arifin B, et al., (2012) perairan Bungus Teluk Kabung Kota Padang diketahui kandungan logam $\mathrm{Cr}$ dan $\mathrm{Pb}$ telah melampaui standar baku mutu air laut, sedangkan logam $\mathrm{Cd}$ dan $\mathrm{Cu}$ belum melewati standar baku mutu air laut yang ditetapkan oleh Keputusan Menteri Negara Lingkungan Hidup No. 51 Tahun 2004. Berdasarkan 
penelitian tersebut, maka perlu dilakukan penelitian

$\mathrm{Cd}$ dan $\mathrm{Cu}$ pada sedimen permukaan dan air permukaan pada 4 muara sungai besar di Kota Padang, mengingat sebagian besar masyarakat di sekitar pantai banyak menggantungkan kehidupan dengan menangkap ikan. Pertimbangan lain daerah ini juga sangat berpotensi dalam pengembangan daerah wisata karena pantainya yang indah dan kaya akan keanekaragaman hayati. Daerah ini juga dijadikan tempat jalur pelabuhan bagi para nelayan yang menggunakan perahu mesin, diduga dapat menambah kandungan polutan dari sisa minyak yang dipakai untuk mesin

\section{METODE PENELITIAN}

Penelitian ini dilaksanakan pada Bulan Mei 2018 dengan mengambil sampel di 4 sungai besar yang berada di wilayah Kota Padang Provinsi Sumatera Barat, lokasi penelitian dapat dilihat pada Gambar 1.

Masing-masing stasiun (sungai) ditentukan dua substasiun yaitu di muara sungai dan $\pm 600 \mathrm{~m}$ ke arah hulu. Sampel sedimen dan air permukaan diambil pada masing-masing substasiun yang telah ditetapkan. Sampel sedimen diambil sebanyak kurang lebih 500gr untuk dianalisis tekstur sedimen dan kandungan logam berat $(\mathrm{Pb}, \mathrm{Cu}$ dan $\mathrm{Cd})$ dan sampel air permukaan diambil dengan botol ukuran $100 \mathrm{ml}$.Sampel selanjutnya dimasukkan dalam cool box untuk mengurangi aktivitas mikroorganisme dalam sampel dan selanjutnya dibawa kelaboratorium untuk selanjutnya dianalisis.Pada masing-masing substasiun juga dilakukan Pengukuran parameter lingkungan yang bertujuan untuk menggambarkan kondisi perairan pada saat penelitian. Parameter lingkungan yang diukur adalah suhu, $\mathrm{pH}$, salinitas, kecerahan, dan kecepatan arus.

Analisis kandungan total logam berat dalam sedimen dilakukan dengan mengambil sampel lebih lanjut kandungan logam berat $\mathrm{Pb}$, seberat 500 gr kemudian di keringkan dalam oven pada suhu $80^{\circ} \mathrm{C}$ sampai dicapai berat konstan (Mucha et al., 2003; Yap et al., 2002). Kemudian sedimen yang telah kering dihancurkan dengan menggunakan alat penumbuk dan selanjutnya diayak dengan menggunakan saringan berukuran 63 mikron.Antara 0,5 - 1,0 gr sampel sedimen (63 mikron) didestruksi dalam kombinasi larutan $\mathrm{HNO} 3$ dan $\mathrm{H} 2 \mathrm{SO} 4$ dengan perbandingan 2:1, menggunakan 'block digester' pada suhu rendah $\left(40^{\circ} \mathrm{C}\right)$ selam 1 jam dan kemudian suhu dinaikkan menjadi $140^{\circ} \mathrm{C}$ selama 3 jam. Setelah sampel sedimen terdestruksi secara sempurna, larutan tersebut didinginkan dan diencerkan dengan aquades menjadi $40 \mathrm{ml}$ dan disaring dengan kertas whattman No.1 (untuk menghindari penyumbatan pipa kepiler pada saat analisis sampel dengan AAS) dan disimpan dalam botol sampel. Selanjutnya larutan sampel tersebut dianalisis kandungan logam beratnya dengan AAS.

\section{HASIL DAN PEMBAHASAN}

\section{Kandungan Logam Cd Pada Air Permukaan dan Sedimen Permukaan}

Kandungan logam $\mathrm{Cd}$ pada air berkisar antara 0.0167-0.0374 mg/l, sedangkan kandungan Cd pada sedimen berkisar antara 0.241-0.653 (mg/kg). Kandungan logam Cd pada air permukaan tertinggi diketahui pada substasiun 2.2 (Muara Sungai Banjir Kanal) dengan nilai $0.0374 \mathrm{mg} / \mathrm{l}$ dan terendah pada substasiun 3.1 (Muara Sungai Batang Kuranji) dengan nilai $0.0167 \mathrm{mg} / \mathrm{l}$. Kandungan logam Cd pada sedimen permukaan tertinggi diketahui pada substasiun 3.2 (Muara Sungai Batang Kuranji) dengan nilai $0.653 \mathrm{mg} / \mathrm{kg}$ dan terendah pada substasiun 1.2 (Muara Sungai Batang Arau) dengan nilai $0.241 \mathrm{mg} / \mathrm{kg}$.

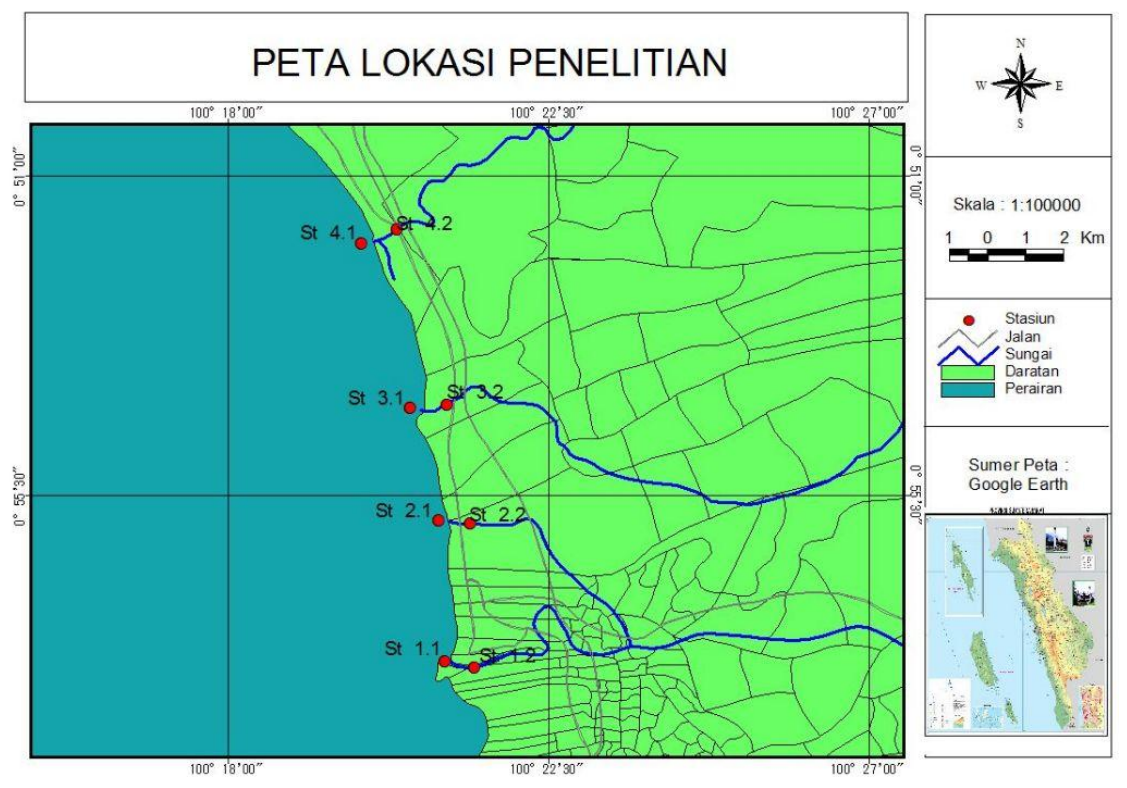

Gambar 1. Peta Lokasi Penelitian 


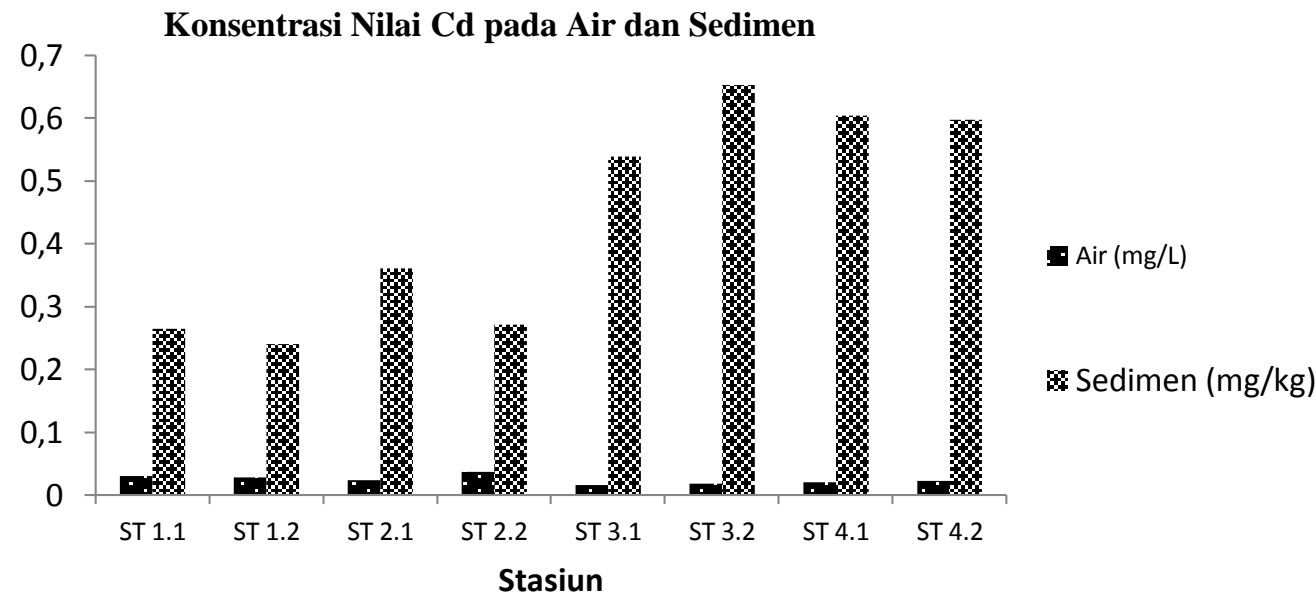

Gambar 1. Histogram Perbandingan Kandungan Logam Cd Pada Air Permukaan dan Sedimen Permukaan

Hasil pengukuran $\mathrm{Cd}$ air permukaan pada masing-masing substasiun diketahui semua nilanya diatas nilai baku mutu air laut untuk biota hidup KEPMENLH No. 51 Tahun 2004 yaitu dengan nilai $0.01 \mathrm{mg} / \mathrm{l}$. Menurut Palar (1994), Cd bersifat racun dan merugikan bagi semua organisme hidup, bahkan juga berbahaya untuk manusia. Kelarutan $\mathrm{Cd}$ dalam konsentrasi tertentu dapat membunuh biota perairan. Biota-biota yang tergolong bangsa udang-udangan (crustacea) akan mengalami kematian dalam selang waktu 24 - 504 jam bila terlarut logam atau persenyawaan Cd sebesar 0.005-0.15 mg/l. Untuk biota-biota yang tergolong ke dalam bangsa serangga (insecta) akan mengalami kematian dalam selang waktu 24-672 jam bila terlarut logam $\mathrm{Cd}$ atau persenyawaan Cd sebesar 0.003-18.0 ppm. Sedangkan untuk biota-biota perairan yang tergolong ke dalam keluarga oligochaeta akan mengalami kematian dalam selang waktu 24-96 jam bila terlarut logam $\mathrm{Cd}$ atau persenyawaannya sebesar 0.0028$4.6 \mathrm{mg} / 1$.

Menurut Connell dan Miller (1995), pengaruh subletal logam berat, seperti $\mathrm{Cd}$ mengakibatkan perubahan secara histologist ataupun morfologis dalam jaringan berbagai jenis ikan dan krustasea yang merupakan pengaruh sekunder dari gangguan pada proses enzim yang terlibat dalam penggunaan makanan. Perubahan morfologis tersebut antara lain: penggantian sel-sel mukus pada epitelinsang oleh selsel klorida dan kerusakan tulangbelakang. Selain itu, logam-logam berat dalam konsentrasi yang relatif rendah sudah menghambatlaju pertumbuhan dan perkembangbiakan vertebratadan invertebrata.

\section{Kandungan Logam Cu Pada Air Permukaan dan Sedimen Permukaan}

Kandungan logam $\mathrm{Cu}$ pada air berkisar antara 0.0155-0.0365 mg/l, sedangkan kandungan $\mathrm{Cu}$ pada sedimen berkisar antara 0.128-0.424 (mg/kg). Kandungan logam $\mathrm{Cu}$ pada air permukaan tertinggi diketahui pada substasiun 1.1 (Muara Sungai Batang Arau) dengan nilai $0.0365 \mathrm{mg} / \mathrm{l}$ dan terendah pada substasiun 2.2 (Muara Sungai Banjir Kanal Muara) dengan nilai $0.0155 \mathrm{mg} / \mathrm{l}$. Kandungan $\operatorname{logam} \mathrm{Cu}$ pada sedimen permukaan tertinggi diketahui pada substasiun 3.1 (Muara Sungai Batang Kuranji) dengan nilai $0.424 \mathrm{mg} / \mathrm{kg}$ dan terendah pada substasiun 1.2 (Muara Sungai Batang Arau) dengan nilai $0.128 \mathrm{mg} / \mathrm{kg}$.

\section{Kandungan Logam Cu pada Air dan Sedimen}

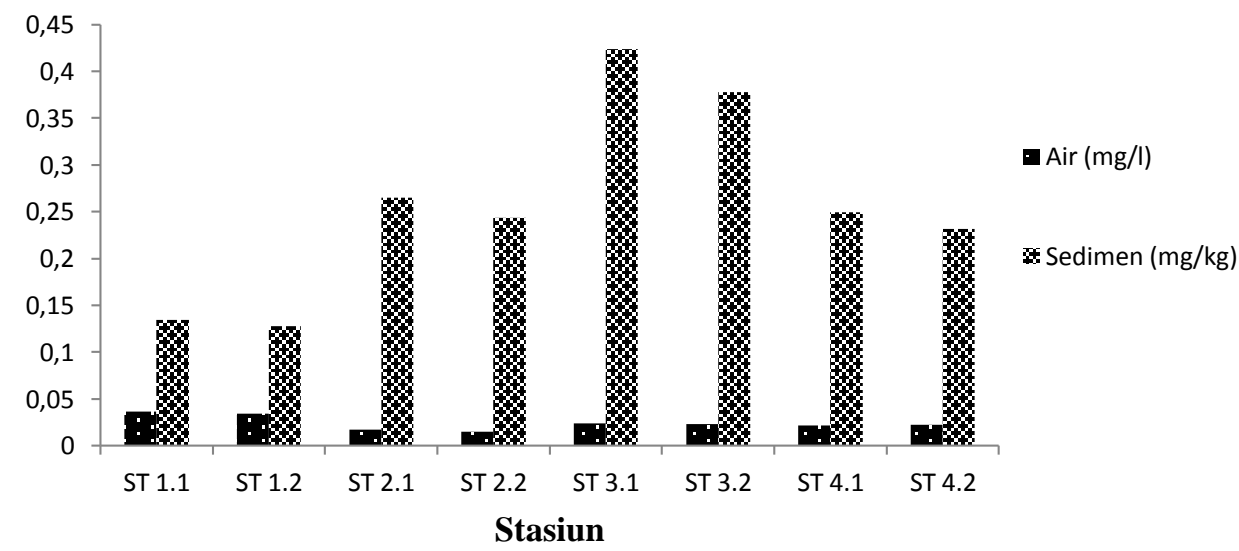

Gambar 2. Histogram Perbandingan Kandungan Logam Cu Pada Air Permukaan dan Sedimen Permukaan 
Hasil pengukuran $\mathrm{Cu}$ air permukaan pada masing-masing substasiun diketahui semua nilanya dibawah nilai baku mutu air laut untuk biota hidup KEPMENLH No. 51 Tahun 2004 yaitu dengan nilai $0.05 \mathrm{mg} / \mathrm{l} . \mathrm{Cu}$ termasuk dalam kelompok logam esensial, dan dalam kadar yang rendah dibutuhkan oleh organisme sebagai ko-enzim dalam proses metabolisme tubuh dan sifat racunnya baru muncul dalam kadar yang tinggi. Biota perairan sangat peka terhadap kelebihan $\mathrm{Cu}$ dalam badan perairan tempat hidupnya.

Menurut Bryan (1976) konsentrasi Cu terlarut dalam air laut sebesar $0,01 \mathrm{mg} / \mathrm{l}$ dapat mengakibatkan kematian fitoplankton. Kematian tersebut disebabkan daya racun $\mathrm{Cu}$ telah menghambat aktivitas enzim dalam pembelahan sel fitoplankton. Jenis-jenis yang termasuk dalam keluarga crustasea akan mengalami kematian dalam waktu 96 jam, bila konsentrasi $\mathrm{Cu}$ berada dalam kisaran 0.17-100 mg/l. Dalam jangka waktu yang sama, biota yang tergolong ke dalam keluarga moluska akan mengalami kematian bila kadar $\mathrm{Cu}$ yang terlarut berkisar 0.16-0.5 ppm. Kadar $\mathrm{Cu}$ sebesar 2.5-3.0 mg/l dalam perairan dapat membunuh ikan-ikan.

Hasil pengukuran $\mathrm{Pb}$ air permukaan pada masing-masing substasiun diketahui semua nilanya dibawah nilai baku mutu air laut untuk biota hidup KEPMENLH No. 51 Tahun 2004 yaitu dengan nilai $0.05 \mathrm{mg} / \mathrm{l}$. Berdasarkan penelitian yang pernah dilakukan oleh Murphy, (1979) diketahui bahwa biota-biota perairan seperti crustacea akan mengalami kematian apabila biota itersebut berada di perairan yang terlarut $\mathrm{Pb}$ dengan konsentrasi 2.75 $49.0 \mathrm{mg} / \mathrm{l}$ setelah 245 jam. Sedangkan biota perairan lainnya, yang dikelompokkan dalam golongan insecta akan mengalami kematian dalam rentang waktu yang lebih panjang antara 168-336 jam bila perairan tempat hidupnya terlarut $\mathrm{Pb}$ sebesar 3.5-64.0 $\mathrm{mg} / \mathrm{l}$.

Menurut Darmono (1995), Pb yang masukke dalam tubuh dapat menyebabkan toksisitas padasel
Menurut Darmono (2006), keberadaan logam berat $\mathrm{Cu}$ di perairan yangberikatan dengan unsureunsur lainnya dapat bersifatracun (toksik) yang umumnya berasal dari daerah industry yang berada di sekitar perairan. Connel dan Miller (1995) bahwaakumulasi logam berat dapat terjadi karena prosesbioakumulasi secara terus menerus dan prosesbiomagnifikasi melalui rantai makanan (food chain) pada hewan air.

\section{Kandungan Logam Pb Pada Air Permukaan dan Sedimen Permukaan}

Kandungan logam $\mathrm{Pb}$ pada air berkisar antara 0.0155-0.0378 mg/l, sedangkan kandungan $\mathrm{Pb}$ pada sedimen berkisar antara 0.0265-0.225 (mg/kg). Kandungan logam $\mathrm{Pb}$ pada air permukaan tertinggi diketahui pada substasiun 3.1 (Muara Sungai Batang Kuranji) dengan nilai $0.0378 \mathrm{mg} / \mathrm{L}$ dan terendah pada substasiun 1.1 (Muara Sungai Batang Arau) dengan nilai $0.0155 \mathrm{mg} / \mathrm{L}$. Kandungan logam $\mathrm{Pb}$ pada sedimen permukaan tertinggi diketahui pada substasiun 3.2 (Muara Sungai Batang Kuranji) dengan nilai $0.225 \mathrm{mg} / \mathrm{kg}$ dan terendah pada substasiun 4.2 (Muara Sungai Panjalinan) dengan nilai $0.0265 \mathrm{mg} / \mathrm{kg}$.

darah merah, jaringan lunak (ginjal dan hati), tulang,dan jaringan keras (gigi dan tulang rawan). Diantarajaringan tubuh ini, tulang dan jaringan keras dapatmenyimpan $90-95 \%$ total $\mathrm{Pb}$ yang disimpan tubuh.Jaringan tubuh tersebut menyerap $\mathrm{Pb}$ dari saluranpencernaan dengan bantuan aliran darah. Penyerapan $\mathrm{Pb}$ dipengaruhi oleh kompetisi dan interaksi denganlogam lain.Menurut Tarigan et al, (2003), pencemaran perairan olehlogam berat didukung oleh sifat logam berat yaitu: sulitdidegradasi sehingga keberadaannya di perairan sulituntuk dihilangkan, dapat terakumulasi di dalam tubuhikan, kerang, udang dan tumbuhan air dan berbahayabagi organisme yang mengkonsumsinya, serta mudahterakumulasi di dalam sedimen sehinggakonsentrasinya selalu lebih tinggi daripada di air.

\section{Kandungan Logam Pb pada Air dan Sedimen}

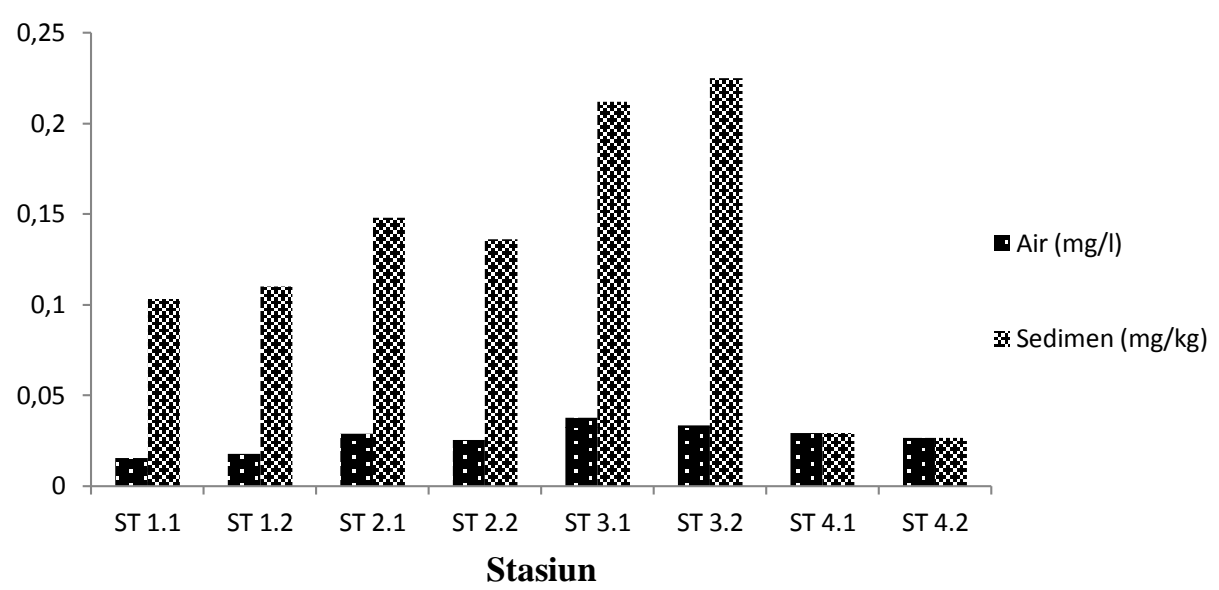

Gambar 3. Histogram Perbandingan Kandungan Logam Pb Pada Air Permukaan dan Sedimen Permukaan 


\section{SIMPULAN}

Berdasarkan hasil mengukuran kandungan logam berat $\mathrm{Cd}, \mathrm{Cu}$ dan $\mathrm{Pb}$ pada air permukaan dan sedimen permukaan di 4 sungai besar yang berada di wilayah Kota Padang Provinsi Sumatera Barat dapat disimpulkan kandungan logam $\mathrm{Cd}$ pada air berkisar antara 0.0167-0.0374 mg/l, sedangkan kandungan $\mathrm{Cd}$ pada sedimen berkisar antara 0.241-0.653 (mg/kg). Nilai Cd pada air permukaan diatas nilai baku mutu air laut untuk biota hidup. Kandungan logam $\mathrm{Cu}$ pada air berkisar antara 0.0155-0.0365 mg/l, sedangkan kandungan $\mathrm{Cd}$ pada sedimen berkisar antara 0.128$0.424(\mathrm{mg} / \mathrm{kg})$. Kandungan logam $\mathrm{Pb}$ pada air berkisar antara 0.0155-0.0378 $\mathrm{mg} / \mathrm{l}$, sedangkan kandungan $\mathrm{Pb}$ pada sedimen berkisar antara 0.0265$0.225(\mathrm{mg} / \mathrm{kg})$. Secara umum, kandungan logam berat pada sedimen permukaan nilainya lebih tinggi dari pada kandungan logam berat di air permukaan karena mudah terakumulasi dan terendapkan pada sedimen permukaan.

\section{UCAPAN TERIMA KASIH}

Ucapan terima kasih kami ucapkan kepada Kepala Direktorat Risat dan Pengabdian Masyarakat, Direktorat Jenderal Penguatan Riset dan Pengembangan, Kementerian Riset, Teknologi dan Pendidikan Tinggi. Sesuai dengan Kontrak penelitian nomor: 025/K10/KM/KONTRAKPENELITIAN/2018.

\section{DAFTAR PUSTAKA}

Amin B, E Afriyani, MA Saputra. 2011. Distribusi Spasial Logam $\mathrm{Pb}$ dan $\mathrm{Cu}$ pada Sedimen dan Air Laut Permukaan di Perairan Tanjung Buton Kabupaten Siak Provinsi Riau. Jurnal Teknologi, Vol 11 (1).

Arifin B, Deswati dan U Loekman. 2012. Analisis Kandungan Logam $\mathrm{Cd}, \mathrm{Cu}, \mathrm{Cr}$ Dan $\mathrm{Pb}$ Dalam Air Laut Di Sekitar Perairan Bungus Teluk Kabung Kota Padang. J Teknik Lingkungan UNAND, Vol 9 (2) : 139-145.

Bryan GW. 1976. In: A. P. M. Lockwood (Ed.), Effects of Pollutants on Aquatic Organisms, Cambridge University Press, Cambridge.
Connell DW \& GJ Miller. 1995. Kimia dan Ekotoksikologi Pencemaran. Terjemahan Y.Koestoer. Penerbit Universitas Indonesia.Jakarta.

Darmono. 1995. Logam Dalam Sistem Biologi Makhluk Hidup. Universitas Indonesia Press. Jakarta.

Darmono. 2006. Lingkungan Hidup dan Pencemaran. UI-Press. Jakarta.

Manahan SE. 2002. Environmental Chemistri, Seventh Edition. Lewis Publisher. New York.

MEN-KLH. 2004. Surat Keputusan Nomor: Kep51/MENKLH/I/2004. tentang Pedoman Penetapan Baku Mutu Lingkungan. Sekretariat Mentri Negara Kependudukan dan Lingkungan Hidup. Jakarta.

Mucha AP, Vasconelos, Bordalo. 2003. Macrobenthic Community in the Douro Estuary: Relation with Trace Metals and Natural Sediment Characteristics. Environmental Pollution, 121: 169-180.

Murphy M. 1979. A Manual for Toxi. Tests with Freswater Macroinvetebrates and A Review of The Effects of Specific Toxicants. University of Wales Institute of Science and Technology Publication.

Palar H. 1994. Pencemaran dan Toksikologi Logam Berat. Penerbit Rineka Cipta. Jakarta.

Rochyatun E, MT Kaisupy, A Rozak. 2006. Distribusi Logam Berat dalam Air dan Sedimen di Perairan Muara Sungai Cisadane. J Makara Sains. Vol 10 (1).

Tarigan Z, Edward, A Rozak. 2003. Kandungan Logam Berat $\mathrm{Pb}, \mathrm{Cd}, \mathrm{Cu}, \mathrm{Zn}$ dan Ni dalam Air Laut dan Sedimen di Muara Sungai Membramo, Papua dalam Kaitannya dengan Kepentingan Budidaya Perikanan. J Makaira Sains, Vol 7 (3).

Yanti EL, Afdal. 2016. Profil Pencemaran Air Sungai Batang Arau Daerah Lubuk Begalung Kota Padang. J Fisika Unand, Vol 5 (2).

Yap CK, A Ismail dan SG Tan. 2003. Concentration of $\mathrm{Cu}, \mathrm{Pb}, \mathrm{Zn}$ in the Green-Lipped Mussel Verna viridis (Linnaeus) from Peninsula Malaysia. Marine Pollution Bulettin, 46 : 1035 1048. 